\title{
The rule of law and African game - a review of some recent trends and concerns
}

\author{
Clive Spinage
}

Increasing denouncement of African game legislation as inappropriate law imposed by the former colonial authorities is viewed with concern and condemned as mistaken. The necessity for the rule of law is argued and the good intent behind the institution of game laws. Abrogation of such laws will not lead to a lessening of the increasing destruction of African wildlife. The author was consultant to the Government of Botswana for the drafting of its new Wildlife Conservation and National Parks Act, 1992.

\section{Introduction}

'Game laws' and poaching, the latter being the taking of game contrary to legislation controlling such taking, basically refer to ownership. Logically, no one can own a wild animal because that is a contradiction in terms: the question of ownership arises once it has been 'taken' - killed, wounded or captured - and therefore no longer free of humans. Consequently, governments seldom claim ownership of wild animals, but do impose regulations concerning them once they have been rendered into possession, or 'taken'.

Just as in Britain in the 1870 s there was an anti-game-law movement, so in recent years has there emerged a European-fostered antigame-law attitude with respect to African game laws, stemming on the one hand from socialist-inspired motives of the rejection of hunting rights for what is perceived as an elite, and on the other from providing an incentive to peasant landowners to manage their game on a sustainable basis by freeing it of state control. Founded in these approaches, the abrogation of game laws is mistakenly promoted as the answer to modulating the increasing rate of destruction of game in Africa. It is alleged that, because legislation controlling the taking of game animals was introduced by colonial authorities replacing tribal custom, this discredited the resource among the rural masses (Child, 1995). But if such laws remain little altered on the statute books of independent Africa today (Child, 1995), then it must be because suitable, acceptable alternatives have not been deemed appropriate. Whereas it was feared that at independence many African countries would sweep away their former colonial conservation policies, and the Arusha Conference was called in an endeavour to pre-empt such action (Watterson, 1963), the fear was unfounded. African governments wanted to control the resource just as much as the colonial authorities had done.

\section{The introduction of game laws}

The earliest-known European laws connected with game, those of the Salian Franks of $A D$ 507-511, were concerned solely with the stealing of game taken during hunting, particularly domesticated stags used as decoys (Drew, 1991). The Anglo-Saxon laws of the seventh to tenth centuries contain no references to hunting or game, but those of Ine (688-694) are among the earliest of conservation laws in that they imposed penalties for tree-felling and burning (Whitelock, 1955). The tenth-century Welsh laws of Howel Dda (c. 940; Owen, 1841) imply a close season for deer and wild boar but, primarily with reference to deer, are concerned with the privileges of the king's chief huntsman and the king's hunting, the king 
having the right to hunt everywhere in his country. Any freeman apparently also had the right to hunt otter, fox and roebuck (although the earliest-known text has a swarm of bees instead of roebuck). If an animal was found dead it belonged to the owner of the land but the person finding it was entitled to the forequarter. If a person killed a deer on another's land, then he was obliged to give the owner of the land a quarter. Snaring on another's land was punishable by a fine, but the only conservation aspect appeared to be that no person could shoot (with an arrow) a game animal reposing in its resting place (Probert, 1823). The concept of protection during the breeding season became widespread, and in the thirteenth century Kublai Khan imposed a close season on game in his dominions (Polo, 1908).

The earliest laws in Britain, such as those implemented by William I (1066-1087), attributed to an alleged forest law of 1017 decreed by Canute (but the attribution is believed to be spurious), and those of Howel Dda, were related to hunting rights rather than the protection of game. Consideration for the preservation of the game itself really started with Henry VIII in 1523 when it was forbidden to kill hares in the snow because of the ease of tracking them ( $14 \& 15$ Hen 8$)$. In 1533 a close season was imposed on the taking of wildfowl, which had declined because they were being taken during the moult and also when too young to fly. The taking of eggs was also forbidden ( 25 Hen 8). Unlike King John's apparently arbitrary law against the capture of all birds in England in 1209, these later measures were designed to preserve stocks of what was seen as an important food resource. Just as later game laws were imposed to ensure the survival of game, rather than as an irrational, jealous denial to the individual, as is often the rural dweller's interpretation, and, it seems, the anti-colonialist. An English act of 1604 states in its preamble: '...whereby the good thereby meant and hoped hath not succeeded, and thereby great scarcity of the said games in all, or in the most parts of this realm, hath followed, and presently is, and so is like to be, if some remedy be not in that behalf provided' (2 Jac I c. 27).
Those who pressed for the introduction of game laws in Africa at the end of the nineteenth century are portrayed as doing so in order to preserve animals for the white man's sport. Grove (1987), for example, refers to their 'Nimrodic obsessions'. Whereas some of this increasing negative attitude towards the rule of law seems to stem from American liberal thinking and the dream of the 'Old Wild West', in which every colonist assumed right of ownership to what he found on the land, it comes as no surprise to learn that the British authors of such views are usually historians. A negative attitude towards game laws has been fostered in generations of British history graduates who have used Poole's (1951) text, From Domesday Book to Magna Carta 1087-1216, in their curricula. Poole includes an example of a man who died in prison in 1209 for taking a doe, and one of his associates lay for a long time in prison, so that he is nearly dead' and so was released. This is quoted as an example of the tyranny of the forest law administered by the Angevin kings. But large numbers of people imprisoned for minor offences probably died in prison at the time from injury, sickness, disease or starvation. Singling out this case for note because it reflected an infringement of the forest law tells us nothing of attitudes and conditions at the time.

Whereas it may be true to say that the colonial government was 'quick to introduce game laws' in the former Southern Rhodesia, now Zimbabwe (Child, 1995; in fact it was Rhodes's British South Africa Company and not government; for a full review see Mutwira, 1989), the introduction of conservation laws in Cape Colony far pre-dates the British experience in India on which Grove (1987) claims they were based, and the date of the Cape of 1811. As I have shown elsewhere (Spinage, 1991; see also Rabie, 1973), the first conservation law in the Cape, which forbade the shooting of birds, was introduced on 1 January 1657 by Governor Van Riebeeck, within 5 years of his settlement there, because of his concern at the disappearance of birds in the region. It was followed by others in the same year and in 1667, 1668,1680,1687, 1751, 1771 and 1792. In 1680 Governor Simon van 
der Stel introduced the first comprehensive criminal prohibition of unlawful hunting with a licensing system, a hunting season limited to 2 months of the year, and the condition that a part of any lawfully hunted hippopotamus carcass must be left for the wild animals to eat. It is extremely unlikely that these early Dutch colonists were motivated by Nimrodic obsessions or delusions of imperial grandeur. The laws were a response to the disappearance of game in the face of an increasing human population and the demands upon it that this engendered, not only by settlers but by the victualling of increasing numbers of ships passing the Cape.

By the end of the nineteenth century, however, in a mere 50 years, a huge wanton destruction of game had already taken place in South Africa, outside the jurisdiction of the Cape. This was the result of both land settlement and the hunting of animals for profit, namely for their skins. It was this excessive profit-motivated destruction that influenced colonial game law policy in not permitting private ownership and discouraging economic incentive (e.g. see Caldwell, 1926). But the event that precipitated the introduction of game laws on a wider scale in Africa was undoubtedly the great rinderpest pandemic that swept the length and breadth of the continent in 1889-98. Pockets of game were still left, even in South Africa, but in the eyes of observers, rinderpest threatened to annihilate all the remaining artiodactyls.

\section{Who owns the game?}

After centuries of discontent in Britain, which was generally considered to have started with the Norman invasion, although the tenth century laws of Howel Dda had already established a royal prerogative over game in Wales, the Game Act of 1831 gave everyone the qualified right to ownership of game on their own land, i.e. ownership once the game was capable of being owned. One could not, for example, claim ownership of pheasants that had flown on to a neighbour's land. In Botswana, in the 1980s, objections were made that, because game was a common resource no person should have the right to ownership of an animal simply because it happened to cross a boundary on to that person's land. The corollary would be that the more land a landowner possessed, the more of the common resource would that person lay claim to. To obviate this perceived injustice, control by the central authority was the preferred option.

In Africa, with its profusion of game and vast open spaces, early administrators doubtless saw it as impossible to prove where a game animal or a product of such had originated. The solution was seen as imposing overall control, not simply trying to imitate the 'king' as Graham (1973) suggested. Some critics give the impression that game laws were drawn out of a hat, but before laws were drawn up in the nineteenth century, both when changes in British law were mooted and proposals made for the 1900 London Convention for the Preservation of Animals, Birds and Fish in Africa (which was organized by the UK to institute and co-ordinate laws for the preservation of game in Africa among the colonial powers), the principle of precedent in English law was followed and the British Government consulted existing foreign, colonial and home legislation. When game laws were formulated for Africa, the changes in British game law would have been fresh in the minds of the politicians.

The British Government has also been accused of tardiness in creating national parks in Africa (Graham, 1973), America having had national parks since 1872 . Britain was reluctant to do so because this meant apportioning land to the Crown. Hence, in Botswana game reserves, which operate in almost the same way as national parks (they are not hunting areas as in some countries), were created on tribal land; and national parks, with their concept of inviolability, only on existing Crown land.

\section{Lack of enforcement}

Where colonial game laws were on the statute book but not enforced, the indigenous inhabitants, far away from administrative control, 
did not look after their wildlife. A case in point is that of western Sudan. Having eliminated much of the game in their area by the 1930s, the Kreich inhabitants poached over the border in the Central African Republic, then a part of French Equatorial Africa, much to the chagrin of the French authorities (Gromier, 1941). They continue to do so today.

In Nigeria hunting was mainly restricted to indigenous people either conforming to the law, which made provision for them, or not. By 1905 a serious diminution of game was reported and little has survived to this day. In most countries, despite laws, very little control was exerted. In Kenya, from 1908 to 1923 the main preoccupation of the Game Department was the licensing and regulation of sporthunters and the collection of revenue from ivory, which far outweighed any control of African hunting (Steinhart, 1989), the policing of which was either ignored or left to the district administration, which gave it a low priority. The East African Protectorate's East Africa Game Regulations, 1900, made it clear that the law was primarily directed at the settler and visiting hunter, while collectors were empowered to grant permission to native chiefs to hunt in their tribal areas. This provision was retained in the 1921 Game Ordinance of Kenya Colony but dropped from the Wild Animals Protection Ordinance, 1951. Prior to this latter ordinance, if the intent of the law was not observed, then it was the fault of the District authorities who either failed to grant hunting rights or imposed strict conditions.

It was not official British colonial policy to reserve hunting for the 'imperial elite' as Mackenzie (1988) suggested. Mackenzie (1987) recorded that Sir Frederick Jackson had expressed surprise that the Administration of the East African Protectorate (now Kenya) had not attempted to alleviate famine in Kamba in 1899 'by permitting hunting'. Jackson (1930) actually wrote that he never understood why the Administration and the Railway together did not send some officials to shoot game for the people. Possibly it was because the Administration thought that the people could hunt for themselves. There was no suggestion that they were forbidden to do so. Indeed, Mackenzie (1988) also quoted Ainsworth reporting on the operation of game laws in Ukamba Province in 1900 as stating that, although the Wakamba hunted, they killed few animals: 'Hunting became particularly important in time of famine, but now that the recent famine was over, he [Ainsworth] argued, hunting should be stopped'. Stone (1972) alleged that the Wakamba ignored the Game Ordinance, although the authorities were concerned with stopping elephant poaching. But if the Wakamba had been authorized at the District level to hunt, then perhaps the district authority did not 'fail' as Stone suggested.

In those countries outside Africa where there were no colonial powers implementing game laws, the larger wildlife has in many cases become almost, if not totally, extinct.

\section{Advocating abrogation}

Gillet (1907), writing for the Society for the Preservation of the Wild Fauna of the Empire (now Fauna \& Flora International), stressed that the rights and necessities of the native people should be the first consideration in the framing of game laws: 'I might even go so far as to say [it would be] criminal, to prevent a tribe or tribes from obtaining their living in the way they have been accustomed to for generations past'.

Clarke and Bell (1984) stated that some of the most successful contemporary wildlife programmes, 'for example in Zimbabwe, are based on reduction or withdrawal of legislative control'. Such sweeping generalization must be deplored as irresponsible. No examples were given, other than Zimbabwe, and even Zimbabwe's approach has yet to be shown to be successful in the long term. It also overlooked the fact that Zimbabwe was one of the more extreme cases of African colonial rule, where land dispossession is likely to have been the primary cause of antagonism to colonial authority.

Southern Rhodesia (now Zimbabwe) was, from 1890 to 1923 , run by the British South Africa Company under charter before receiving 
its constitution. Whereas the charter had prescribed respect for native customary law regarding the holding of land and other personal rights, these provisions appear to have been either ignored or steadily eroded, especially following the Order in Council of 1898, which prohibited the British South Africa Company from imposing any disabilities on Africans that did not apply equally to Europeans, without the sanction of the Secretary of State. This provision could be used in a manner entirely opposite to that intended.

The fact that the Africans were denied guns was a political issue, a consequence of the Matabele uprising, and not connected to hunting per se.

It is misleading to state that Zimbabwe has withdrawn legislative control (e.g. Clarke and Bell, 1986). It still has a Parks and Wild Life Act, 1975, of 121 sections. In certain areas people have been granted the right to ownership of game on their own land, but there remains legal control of rare and endangered species and of certain aspects of trade. The right to ownership of game on one's own land exists in Britain today after centuries of lobbying, yet there are many wild species that it is now prohibited to take, whether on one's own land or not (Wildlife and Countryside Act, 1981).

Whereas the Zimbabwe experience is frequently held up as a model answer to Africa's wildlife problems, Zimbabwe's situation is historically very different, for example, from that of neighbouring Botswana. In the latter country the indigenous peoples were not dispossessed of their lands and the game laws introduced by the Protectorate authority obeyed the maxim that they did not apply to the indigenous inhabitants but to foreigners (Spinage, 1991). Each tribe was responsible for its own wildlife matters but urged to make game laws in line with the central authority, which some did and some did not. At independence in 1966 the principal game law became applicable to all. The following year the tribes committed themselves to placing their separate regulations on the statute book. It was not until 1979 that universally applicable regulations were introduced, dispossessing the tribes of their individual control. Although the reasons for this were probably largely political, being the first step in taking away the power of the chiefs, it was considered that the numbers of game being hunted each year, or offered for hunting, were excessive. Botswana may have been unique in Africa in that the cooperation of the chiefs was sought to control hunting of game rather than control being imposed by the central authority, but the chiefs' control largely broke down in the post-war years (Spinage, 1992).

\section{Game without game laws?}

While not advocating the repeal of laws but, on the contrary, a more rigorous enforcement, the romantic viewpoint is exemplified by MacKinnon and MacKinnon (1986), who wrote, 'So long as the Bushmen continue to hunt with their traditional weapons, bows and spears, their small harvest of game is no threat to wildlife populations'. The reality is very different. Few San (Bushmen) in Botswana now hunt with their traditional weapons but are loaned guns by traders who 'pay' them a few cans of beer to supply large quantities of game skins, which the traders smuggle out of the Central Kalahari Game Reserve, for example, by the pick-up load. Other San, mounted on horseback, run down game, particularly gemsbok, and spear it. Accomplished trackers and naturalists as they are, the San are extremely damaging to wildlife populations. While they may still be aware of their traditional beliefs and customs, their society has become too disrupted for such to be treated as other than memories of a bygone age.

It is a moot point that the colonial laws discredited the resource among the rural masses (Child, 1995), because, as I have explained elsewhere (Spinage, 1991), African societies formerly constrained by strict taboos and customs relating to hunting could appreciate the rationale of game laws, even if they did not like them. Probably in most former African societies, as in Botswana, individuals did not have unrestricted access to game. Regarded as 
a common resource, game was controlled by the chief in the same way as the state controls game today. The chiefs often went further, even deciding who ate what parts of a carcass.

Had it not been for laws it is doubtful whether the giraffe and the hippopotamus would still exist in Botswana; the same can be said of many species in other African countries. Without the laws Africa today would have no national parks and little wildlife. The increasing pressures being placed upon wildlife cannot be resolved by the abrogation of game laws and an attempt to return to such tribal controls as might have existed in the past. Few Africans now demonstrate traditional tribal affinities and it is naive to suppose that such controls as tribal custom exercised when human populations were much smaller, less mobile and not economically acquisitive, as well as lacking the products of western technology, could work today.

\section{Abrogating game laws}

There is a number of precedents concerning the rejection of game laws following revolution. In Britain's Civil War, the Long Parliament in 1642 took possession of all the royal forests and repealed many of the forest laws, with the result that almost all deer on the large estates, such as Windsor Great Park, were poached. In 1651 Parliament examined the state of the forests, vesting them in trustees with a view to selling; at the same time doing an about-turn by issuing an act forbidding the killing of deer without an owner's consent, but by then with little effect. Local gentry and commoners, who had so often complained of the royal forests in the past, now petitioned Cromwell for fear of losing rights such as cottager grazing if the forests were sold into private hands. This position is paralleled in Britain 340 years later, with the Government proposing to sell off the Crown forests and with those who use them for enjoyment objecting, fearing that access will be denied under private ownership. In 1655 Cromwell had appointed a commission to look into the matter and the commissioners recommended that the former rights of the head of state over forests be re-established. No such action was taken, however, and reinstatement did not take place until the restoration of the monarchy in 1658. As Trench (1967) stated, the commissioners' decision was a remarkable vindication of the royal forest laws. The forest law remained on the statute book until 1971 when the incumbent Labour Government abrogated it but with the proviso that 'no existing rights of common or pannage originating in the forest law shall be affected by the abrogation...' (Wild Creatures and Forest Laws Act, 1971). The law also took away any prerogative right of the monarch to wild creatures (except royal fish [sturgeon] and swans) and 'any prerogative right to set aside land or water for the breeding, support or taking of wild creatures...'.

Following the 1790 proclamation of the revolution in France, the seventeenth century game laws that forbade hunting except by the king and his appointees were abrogated and hunting made the right of everyone on his own possessions. Yet in 1844 it was necessary to introduce comprehensive game legislation to halt the destruction because the qualification of land ownership was ignored and it was feared that there would soon be no game left (Gillon and de Villepin, 1844). Game laws have, therefore, been seen to be necessary even by revolutionary governments because their abolition leads to an abuse of a common wealth.

\section{The decline of game}

Because game laws are not 100 per cent effective does not mean to say that they are either bad or inappropriate. Most countries have a law against murder, but murders still occur.

Child's (1995) statement that, 'Arguably, these laws have done more than anything, other than habitat loss, to deplete wildlife in the 96 per cent of sub-Saharan Africa outside protected areas...because they discredited the resource among the rural masses who became marginalized from their wildlife', may have applied to the former Southern Rhodesia 
(although, see Mutwira, 1989), but it is grossly misleading to promote as a general concept. Other than habitat loss, loss of game can be attributed to the increasing availability of firearms to the local people from the middle of the nineteenth century and to the exponential rise in human population, coupled with urban concentrations hungry for game meat. The latter situation was mirrored in Britain in the nineteenth century 'poaching wars', where the newly affluent traders and other townspeople, like the country gentry, wanted to have game on their tables. The only way to satisfy the demand was, in fact, to steal it from the latter.

Failure to rationalize the demands of increasing human population was exemplified by a critic of the game laws in Botswana in a report to the Government. The report stated that, whereas in 1979 in the western region of the country 30 per cent of households obtained a major proportion of their income from legitimate hunting, in 1989 this had fallen to some 10 per cent due to restrictive legislation. What was not pointed out was that, for every 100 animals required for consumption in 1979, 160 would be required in 1989 due to human population increase. Moreover, the 100 animals present in 1979 had declined to an average of 62 in 1989 due to drought losses. Thus the 10 per cent of the increased number of households were, in effect, taking relatively more animals from the available stock than had been the case in 1979.

Added to human population pressure on game in Africa, and inextricably linked with it, was significant destruction in the name of tsetse control. Although in some areas such 'control' amounted to a sustained offtake (Child et al., 1970) this was not the universal result.

\section{Conclusions}

To dub the law-making a 'Nimrodic obsession' (Grove, 1987) was to do a disservice to those far-sighted people who lobbied to have game laws instituted; it is because of them that the fauna exists today. Although many may have been keen hunters in their youth, by the time they became elder statesmen they had often changed their views, as is so frequently the case. A well-known, early hunter in South Africa, William Cotton Oswell, although he did not lobby for laws, illustrates this change of heart. At the age of 75 he wrote: 'I am sorry now for all the fine old beasts that I have killed' (Oswell, 1894).

In Britain poaching has perhaps never been worse nor more widespread than it is today, showing that granting the right to ownership of game on one's own land does not remove the problem. Nor is it related to poverty. In Britain the cause is greed engendered by affluence. Many can now afford to buy a gun and a vehicle and head off into the country to try their luck dressed in the obligatory disruptive camouflage-pattern jacket, while numerous magazines devoted to shooting and other forms of hunting encourage poaching through encouraging hunting, because all the game is on private or Crown land.

Game laws were instituted in Africa primarily to regulate visiting hunters but later became of more importance in the deterrence of commercial poaching. Whereas the original good intentions of safeguarding native rights in most cases fell by the wayside, Botswana being an exception, this was not originally a deliberate policy on the part of the British Government. An American hunter visiting Kenya in 1913 wrote, 'The richest country is generally occupied by natives, and the government scrupulously protects them in their ownership and control' (Hepburn, 1913). Although the London Convention of 1900, which was never fully ratified, contained no safeguards of native rights, the 1933 Convention did with respect to hunting (Art. 8 [2I), but not with respect to land taken over for national parks or reserves. However, the 1933 Kenya Land Commission, for example, supported the Game Warden's proposal for a national park near Mount Marsabit, the Matthews and Ndoto Ranges, Mount Nyiro and the Horr Valley, 'subject to adequate protection of native rights and interests' (section $884[\mathrm{e}])$, it being noted that no displacement was envisaged of the few native people that inhabited the area (Carter $e t$ al., 1934). 
Nothing will be solved by encouraging a contempt for law. The laws will no longer be necessary only when there is nothing left to protect. Neither can we turn the clock back in some vain hope that Africans, the majority of whom has been born since colonial rule ended, will revert to traditional customary behaviours as far as this particular aspect of their lives is concerned. Whereas I do not oppose the measures introduced in Zimbabwe, some aspects of the justification put forward are unacceptable. It is claimed, as a generalization, that the answer to current pressures on Africa's game is to foster an economic interest in maintaining it by granting the right of ownership to game on one's own land. This may have the desired outcome in carefully controlled circumstances, but experience shows that abuse will deny it success in many instances.

In his theory of the alleged development of the hunting code whereby the killing of animals 'lost economic and achieved ritual [i.e. sporting] significance' Mackenzie (1988) persistently ignored the fact that it is the rise in human numbers that increasingly dictates legislative control, a fact appreciated by Dawson (1694) in the seventeenth century, quoted in extenso in Spinage (1991). Restricting the taking of game to sport-hunters is a way of limiting offtake. Local or subsistence hunters are the first to suffer from this process because they are initially the most numerous category of hunters, whether peasants in Africa or in mediaeval England. As long as the law exists, it is wrong to contravene it and to print the word poacher in inverted commas, as increasingly happens, is to disparage the rule of law and it is irresponsible of conservation organizations to do so.

\section{References}

Caldwell, K. 1926. The commercialisation of game. J. Soc. Pres. Fauna Emp. NS, 7, 83-90.

Carter, M., Hemsted, R.W., Wilson, F.O'B. and Fazan, S.H. 1934. Report of the Kenya Land Commission. HMSO, London.

Child, G. 1995. Managing wildlife successfully in Zimbabwe. Oryx, 29, 171-177.

Child, G., Smith, P. and von Richter, W. 1970. Tsetse control hunting as a measure of large mammal population trends in the Okavango Delta, Botswana. Mammalia, 34, 34-75.

Clarke, J.E. and Bell, R.H.V. 1984. Wildlife legislation. In Conservation and Wildlife Management in Africa (eds R. H. V. Bell and E. McShane-Caluzi), pp. 479-499. US Peace Corps.

Dawson, G. 1694. Origo legum: or a Treatise of the Origin of Laws. Richard Chiswell, London.

Drew, K.F. 1991. The Laws of the Salian Franks. University of Pennsylvania Press, Philadelphia.

Gillet, F. 1907. Game laws and regulations. J. Soc. Pres. Wild Fauna of the Empire, III, 80-82.

Gillon, J.-L. and Villepin, G. de. 1844. Nouveau Code des Chasses. Librairie Administrative de Paul Dupont, Paris.

Graham, A. 1973. The Gardeners of Eden. George Allen and Unwin Ltd, London.

Gromier, E. 1941. La Vie des Animaux Sauvages $d u$ Chari Oriental. Payot, Paris.

Grove, R. 1987. Early themes in African conservation: the Cape in the nineteenth century. In Conservation in Africa: People, Policies and Practice (eds D. Anderson and R. Grove), pp. 21-39. Cambridge University Press, Cambridge.

Hepburn, A.B. 1913. The Story of an Outing. Harper and Brothers, New York.

Jackson, F. 1930. Early Days in East Africa. Edward Arnold \& Co., London.

London Convention for the Protection of African Fauna and Flora. 1933. HMSO, London.

Mackenzie, J.M. 1987. Chivalry, social Darwinism and ritualised killing: the hunting ethos in Central Africa up to 1914. In Conservation in Africa: People, Policies and Practice (eds D. Anderson and R. Grove) pp. 41-61. Cambridge University Press, Cambridge.

Mackenzie, J.M. 1988. The Empire of Nature. Manchester University Press, Manchester.

MacKinnon, J. and MacKinnon, K. 1986. Review of the Protected Areas System in the Afrotropical Realm. IUCN, Gland.

Mutwira, R. 1989. Southern Rhodesian wildlife policy (1890-1953): a question of condoning game slaughter? J. Sthn. Afr. Studies, 15, 250-262.

Oswell, W.C. 1894. South Africa fifty years ago. In Big Game Shooting (ed. C. Phillips-Wolley), Vol. 1, pp. 1-453. Longmans, Green and Co., London.

Owen, A. 1841. Ancient Laws and Institutes of Wales. Vols 1 and 2. Commissioners of the Public Records of the Kingdom, London.

Polo, M. 1908. The Travels of Marco Polo. J. M. Dent \& Sons Ltd, London.

Poole, A.L. 1951. From Domesday Book to Magna Carta 1087-1216. The Clarendon Press, Oxford.

Probert, W. 1823. The Ancient Laws of Cambria. London. 
Rabie, A. 1973. Wildlife conservation and the law. Comparative and International Law Journal of Southern Africa, VI, 145-198.

Spinage, C.A. 1991. History and Evolution of the Fauna Conservation Laws of Botswana. Botswana Society, Gaborone.

Spinage, C.A. 1992. Gleanings of game affairs in the Bechuanaland Protectorate. Botswana Notes and Records, 24, 19-32.

Stone, M.L. 1972. Organized poaching in Kitui District: a failure in district authority, 1900 to 1960. Int. J. Af. Hist. Studies, V, 436-452.

Steinhart, E.I. 1989. Hunters, poachers and gamekeepers: towards a social history of hunting in colonial Kenya. J. Af. Hist. 30, 247-264.
Trench, C.T. 1967. The Poacher and the Squire. Longmans, London.

Watterson, G. (ed.) 1963. Conservation of Nature and Natural Resources in Modern African States. IUCN, Morges.

Whitelock, D. 1955. English Historical Documents c. 500-1042. Eyre \& Spottiswoode, London.

Wild Creatures and Forest Laws Act, 1971. HMSO, London.

Wildlife and Countryside Act, 1981. HMSO, London.

Clive A. Spinage, Wickwood House, Stanford Road, Faringdon, Oxon SN7 8EZ, UK. 